\title{
Engineering Compulsory Food Safety Liability Insurance in China: A Joint Perspective of Public and Private International Law"
}

\author{
Lin Zhang ${ }^{* *}$
}

The Chinese toxic milk scandal raised tremendous global concerns about food safety in China. To repair the tarnished reputation of domestic food production, Chinese authorities focused on compulsory food safety liability insurance. Unfortunately, the introduction of compulsory food safety liability insurance in the Food Safety Law of the PRC has been delayed by the disagreements of Chinese legal scholars. Chinese legal scholars have examined the legitimacy of compulsory food safety liability insurance in China mainly from the standpoint of domestic laws. The valuable insight of international laws has been ignored by them. This article attempts to fill this research gap by scrutinizing the Chinese endeavor of launching compulsory food safety liability insurance through the joint perspective of public and private international law. It further demonstrates that the ideology of human rights of public international law has already penetrated into the body of broadly-interpreted private international law.

\section{Keywords}

Compulsory Food Safety Liability Insurance, China, Public International Law, Broadly-Interpreted Private International Law

* AThis research has been generously funded by "Research Grant of the Civil and Commercial Law Center of Renmin University of China” “教育部人文社会科学重点研究基地中国人民大学民商事法律科学研究中心自主项 目”(14MSFJD820002). The author is indebted to the China Postdoctoral Science Foundation Funded Project and the Max Planck Institute for Comparative and International Private Law for their support of the completion of this research.

** Professor of Law at Fujian Normal University School of Law and Adjunct Professor at Korea University School of Law. LL.B./LL.M.(Shandong Univ. of Sci \& Tech), Ph.D. (Hong Kong). The author may be contacted at: zlin1981@qq.com/ Address: Room 207, School of Law, Fujian Normal University Qishan Campus, Minhou County, Fuzhou, Fujian Province, P.R. China. 


\section{Introduction}

Due to rapid globalization, food logistics have already expanded beyond territorial boundaries. Food safety is thus not only a matter of domestic concern, but also one of ever increasing international concern for public health. ${ }^{1}$ It is no wonder that the food safety issues are regulated under international law covering both the public and private domains.

In 2008, the Chinese toxic milk scandal shocked the entire international community. ${ }^{2}$ It raised tremendous global concern about food safety in China. There was serious public fury over the rampant food adulteration in China. Since this notorious milk incident, Chinese authorities have swiftly taken a series of actions to enhance the safety of domestic food production. ${ }^{3}$ Among these newly-implemented food safety measures, the most salient legal reform was to abolish the Food Hygiene Law, replacing it with the Food Safety Law of the PRC ("FSL") on June 1, 2009."

The enactment of the FSL did not mark the pinnacle of the determination of Chinese authorities to strengthen the regulation of food safety. Four years later, the Legislative Affairs Office of the PRC State Council publicized a draft version of the amended FSL to collect public opinions from October 29, 2013 to November $29,2013 .{ }^{5}$ This round of amendments was intended to further refine the FSL and reinforce its critical role in guaranteeing food quality and safety in China. Of the proposed amendments, the concept of "compulsory food safety liability insurance" ("CFSLI") has aroused the most vigorous discussion among Chinese legal

1 E.g., after the 2008 Chinese melamine milk scandal, many countries banned Chinese dairy food products and the World Health Organization ranked the incident as one of the most serious food safety events handled by it in recent years. See WHO, Emergencies preparedness, response: Questions and Answers on melamine, available at http://www.who.int/ csr/media/faq/QAmelamine/en (last visited on Oct. 4, 2016).

2 Id.

3 On September 17, 2008, the Spokesman of the PRC State Council held a special press conference to summarize the new actions taken by the Chinese authorities to deal with the melamine milk scandal and safeguard food safety. See Press Conference Organized by the PRC State Council to Report the Sanlu Infant Milk Powder Scandal 国务院有关 部门负责人就三鹿牌婴幼儿奶粉重大安全事故的有关情况答记者问, available at http://politics.people.com.cn/ GB/1026/8055387.html (last visited on Oct. 4, 2016).

4 For the full text of the FSL, see Food Safety Law of the PRC 中华人民共和国食品安全法, available at http://www. npc.gov.cn/npc/cwhhy/12jcwh/2015-04/25/content_1934591.htm (last visited on Oct. 4, 2016).

5 Legal Affairs Office of the State Council of the PRC, Notice of the Legal Affairs Office of the State Council of the PRC on Collecting Public Opinions on the Draft Version of the Amended FSL 国务院法制办公室关于公布《中 华人民共和国食品安全法 (修订草案送审稿)》公开征求意见的通知, available at http://www.chinalaw.gov.cn/ article/cazjgg/201310/20131000392889.shtml (last visited on Oct. 26, 2016). 
academics. ${ }^{6}$

CFSLI refers to an insurance scheme that is compulsory for domestic food producers and protects them in the event of food safety incidents. It is evident that CFSLI represents an efficient approach to address the claims of victims of unsafe food, which is recognized by the overwhelming majority of Chinese legal scholars. ${ }^{7}$ Nevertheless, they do not yet fully agree on whether CFSLI ought to be compulsory or voluntary. In addition, there is debate over the different combinations of specific legal measures needed to curb the byproducts of CFSLI, such as moral hazards or adverse selection. $^{8}$ Due to the disagreement of Chinese legal scholars on CFSLI, Chinese authorities finally chose to put it on hold for a while and they did not bring it into the revised FSL that came into effect on October 1, 2015.

This regrettable result shows that the existing discussions of Chinese legal scholars about the CFSLI mainly rely on the perspective of domestic laws, missing the international legal aspects of this issue. Academic ignorance of international laws has partly caused the current deadlock in this vein. This research will thus try to revisit CFSLI from a joint perspective of public and private international law in a balanced manner. Here, private international law embraces the economic dimension of sovereign States and international organizations, such as international economic law.

The remainder of this paper is structured as follows. Part two will illustrate that the right to safe food is an integral component and attribute of the fundamental human rights to adequate food and health. Correspondingly, the right to safe food is a non-derogable obligation of the international community and each State. Part three will analyze the flaws of the currently available remedies in China for victims of mass torts caused by food safety incidents. This part will further show that CFSLI will be a necessary step for China to reinforce its international commitment to protect the right to safe food. Part four will touch on CFSLI from a viewpoint of international economic law, which is an important segment of private international law in its broad sense. It will focus on the WTO legal regime for protecting

$6 \quad I d$.

7 Haichun Yu, Research on the Legislation of Compulsory Food Safety Liability Insurance in China 我国食品安全责任 强制保险的法律构造研究, 3 CHINA LEGAL SCI. 中国法学 244 (2015); Zehua Dong, Research on Construction of Food Security Liability Compulsory Insurance System 论我国食品安全责任强制保险法律制度的构建, 1 L. SCr. MAG. 法 学杂志 123 (2015); Wei Lu, Comparison and Choice of the Legislative Models of Food Safety Liability Insurance 食 品安全责任保险立法模式的比较与选择, 8 L. SCI. 法学 73 (2015); Chengcheng Xin, Research on Introduction of Compulsory Food Safety Liability Insurance in China 我国食品安全责任强制保险制度研究, 3 LEGAL SYSTEM \& SOC'Y 法制与社会 47 (2015). 
consumers' health and safety. Such a consumer-oriented legal regime based on international human rights law allows States to impose necessary health and safety standards on their commodity imports and exports. In turn, the voluntary choice of States to reasonably exercise this right exhibits their commitment to safeguard consumers' health and safety, which are fundamental human rights in the sphere of trade. Part five will first discuss the flawed system of commodity export inspection in China. This system per se represents ex ante measures taken by Chinese authorities to protect foreign consumers' health and safety. It further argues that the overhaul of this dysfunctional system will take time.

As a result, for the time being, CFSLI, as an ex post measure, is urgently needed to complement the flawed ex ante export inspection system in China and to enhance China's exercise of the aforementioned right to protect consumers' health and safety in the export process pursuant to by the WTO law. Part six will contain concluding remarks. This part will indicate that the human rights viewpoint, which is rooted and emphasized in public international law, has already penetrated into the broadlyinterpreted private international law. Governed by this human rights aspect, both public and private international law in its broad sense force the launch of CFSLI by the Chinese authorities in the not-so-distant future.

\section{The Right to Safe Food in the Domain of International Human Rights Law}

The international protection of human rights began rapidly growing and developing in the wake of the catastrophes caused by the Second World War, especially the Nazi Holocaust and the Japanese massacre. ${ }^{9}$ The UN adopted the Universal Declaration of Human Rights ("UDHR”) on December 10, 1948. ${ }^{10}$ It asserted that human rights are a set of fundamental legal norms, regularly respected and protected by international law, and initiated the humanizing of international law towards constitutional justice. ${ }^{11}$ On December 16, 1966, the UN also gave birth to two highly influential international treaties entitled the International Covenant on Civil and Political Rights

9 A. Moravcsik, The Origins of Human Rights Regimes: Democratic Delegation in Postwar Europe, 54 InT'L Org. 230 (2000), available at https://www.princeton.edu/ amoraves/library/origins.pdf(last visited on Oct. 4, 2016).

10 G.A. Res. 217 A (III), available at http://www.un.org/en/universal-declaration-human-rights (last visited on Oct. 4, 2016).

11 T. Meron, The Humanization of International Law 5 (2006). 
("ICCPR") and the International Covenant on Economic, Social and Cultural Rights ("ICESC"). ${ }^{12}$ These two covenants, along with the UDHR, have been referred to as the International Bill of Human Rights and hailed as "a veritable Magna Carta.",13

Under the legal framework of the International Bill of Human Rights, the two expressly-enumerated fundamental human rights that embrace the right to safe food as their essential element are the right to health and the right to adequate food. Article 25, paragraph 1, of the UDHR establishes the right to health by affirming that: "Everyone has the right to a standard of living adequate for the health and well-being of himself and of his family, including food, clothing, housing and medical care and necessary social services." 14 According to this definition, Article 12, paragraph 1, of the ICESC further reinforces this inalienable human right by asserting: "The right of everyone to the enjoyment of the highest attainable standard of physical and mental health." ${ }^{15}$ Furthermore, on August 11, 2000, the United Nations Committee on Economic, Social and Cultural Rights adopted General Comment No. 14. Its purpose is to:

interpret the right to health, as defined in Article 12.1, as an inclusive right extending not only to timely and appropriate health care but also to the underlying determinants of health, such as access to safe and potable water and adequate sanitation, an adequate supply of safe food, nutrition and housing, healthy occupational and environmental conditions, and access to health-related education and information, including on sexual and reproductive health. ${ }^{16}$

As far as legal obligations are concerned, the United Nations Committee on Economic, Social and Cultural Rights clearly indicates in the aforementioned General Comment No. 14 that States are under a general obligation to respect, protect, and fulfill the human right to health and some specific obligations encompassed by this general obligation are of immediate effect regardless of available resources. ${ }^{17}$ Further, to

12 G.A. Res. 2200A (XXI). See the full text of the International Covenant on Civil and Political Rights, available at http:// www.ohchr.org/en/professionalinterest/pages/ccpr.aspx; the full text of the International Covenant on Economic, Social and Cultural Rights, available at http://www.ohchr.org/EN/ProfessionalInterest/Pages/CESCR.aspx (all last visited on Oct. 26, 2016).

13 The phrase of "a veritable Magna Carta" is officially included in the text of The International Bill of Human Rights, available at http://www.ohchr.org/Documents/Publications/FactSheet2Rev.1en.pdf (last visited on Oct. 4, 2016).

14 Supra note 10.

15 Supra note 12.

16 See the full text of General Comment No. 14, available at http://www.refworld.org/pdfid/4538838d0.pdf (last visited on Oct. 4, 2016).

17 Id. 
fulfill the right to health, the General Comment No. 14 illustrates that:

States must ensure provision of health care, including immunization programmes against the major infectious diseases, and ensure equal access for all to the underlying determinants of health, such as nutritiously safe food and potable drinking water, basic sanitation and adequate housing and living conditions and to ensure access to the minimum essential food which is nutritionally adequate and safe, to ensure freedom from hunger to everyone is, inter alia, a core obligation incumbent on states arising from the right to health. ${ }^{18}$

Regarding remedies of the right to health, General Comment No. 14 emphasizes that:

Any person or group who is a victim of a violation of the right to health should have access to effective judicial or other appropriate remedies at both national and international levels. All victims of such violations should be entitled to adequate reparation, which may take the form of restitution, compensation, satisfaction or guarantees of non-repetition. ${ }^{19}$

In other words, States are obligated to supply various remedial measures to restore the right to health when this fundamental human right as a whole or any of its core components, such as the right to safe food, is violated.

Another fundamental human right relating to the right to safe food is the right to 'adequate' food which is defined as "the fundamental rights of everyone to be free from hunger." ${ }^{20}$ According to General Comment No. 12, the right to adequate food is "indivisibly linked to the inherent dignity of the human person and indispensable for the fulfillment of other human rights enshrined in the International Bill of Human Rights." ${ }^{21}$ In order to realize the right to adequate food in practice, General Comment No. 12 specifies "free from adverse substances" as its normative contents. "Free from adverse substances" may refer to:

[s]etting requirements for food safety and for a range of protective measures by both

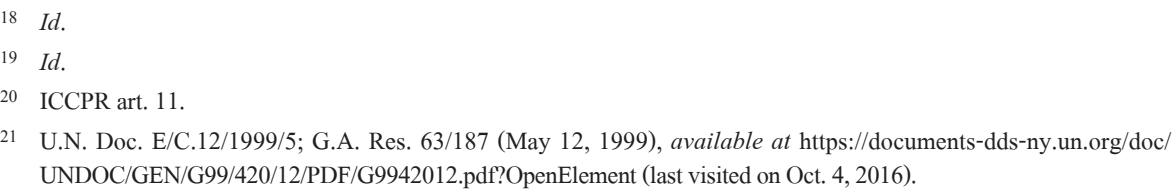


public and private means to prevent contamination of foodstuffs through adulteration and/or through bad environmental hygiene or inappropriate handling at different stages throughout the food chain. ${ }^{23}$

Likewise, the UN General Assembly is holding the same position with the Committee on Economic, Social and Cultural Rights in this regard. In terms of Resolution 63/187 adopted on December 18, 2008, the General Assembly "reaffirms the right of everyone to have access to safe, sufficient and nutritious food, consistent with the right to adequate food and the fundamental right of everyone to be free from hunger, so as to be able to fully develop and maintain his or her physical and mental capacities." $^{24}$

General Comment No. 12 makes it clear that States are obliged to respect, protect, and fulfill the right to adequate food. ${ }^{25}$ For the sake of performing this obligation, States are further required to adopt a national strategy to ensure food and nutrition security for all which "should address critical issues and measures in regard to all aspects of the food system, including the production, processing, distribution, marketing and consumption of safe food, as well as parallel measures in the fields of health, education, employment and social security." ${ }^{26}$ With regard to remedies of the right to adequate food, General Comment No. 12 also provides that:

Any person or group who is a victim of a violation of the right to adequate food should have access to effective judicial or other appropriate remedies at both national and international levels. All victims of such violations are entitled to adequate reparation, which may take the form of restitution, compensation, satisfaction or guarantees of non-repetition. ${ }^{27}$

To realize the remedial power to restore the violated right to adequate food as a whole or any of its core elements including the right to safe food, States in turn are bound to provide an array of efficient remedial measures within their own boundaries.

Following the direction of international human rights law, it is evident that the right to safe food exists as an integral element of the two fundamental human

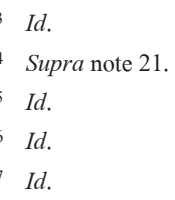


rights - the right to health and the right to adequate food. In order to respect, protect and fulfill the two human rights concerned, State must take efficient measures to safeguard, reinforce and remedy the right to safe food.

\section{Remedial Measures for Violations of the Right to Safe Food in China: Flaws and CFSLI}

As mentioned above, the right to safe food is regarded as a critical attribute of the right to health and the right to adequate food in the domain of international human rights law. States are obliged to efficiently safeguard and remedy the right to safe food for the purpose of realizing the right to health and the right to adequate food. The 2008 melamine milk scandal has caused a disastrous aftermath of mass tort. In the process of providing remedies for victims, China's porous remedial regime for violations of the right to safe food, which mainly consists of mass tort compensation funds, government bailouts and litigation, has been exposed to the public. In these, there is an urgent need for CFSLI to be launched by the Chinese authorities to provide prompt and full compensations for victims of violations of the right to safe food, ${ }^{28}$ and to reinforce China's performance in protecting and fulfilling the two fundamental human rights - the right to health and the right to adequate food.

\section{A. Mass Tort Compensation Funds}

Mass tort compensation funds may refer to a scheme whereby, in the case of mass torts, wrongdoers that are financially capable transfer money to independent and professional caretakers to establish special funds for the purpose of compensating victims. ${ }^{29}$ The selected fund caretakers are fully responsible for the operation of the money pooled in these funds. They are authorized to fairly and scientifically determine the scope, amount, schedule, and other relevant aspects of compensations for victims. In this case, the financial conditions of the compensation funds under their management should be reported to victims and other concerned stakeholders on a regular basis. Once a victim chooses to claim compensation from this type of fund at his/her own discretion, s/he must enter into an agreement with the fund to

$28 \mathrm{Yu}$, supra note 7, 245.

29 Xinbao Zhang \& Yepeng Yue, Mass Tort Compensation Funds: Basic Principles and Institutional Construction 大规 模侵权损害赔偿基金: 基本原理与制度构建, 1 SCI. L. 法律科学 119 (2012). 
simultaneously renounce the right to file a lawsuit against the wrongdoers due to the same infringement. Thus, mass tort compensation funds are deemed an alternative remedial measure to litigation for victims of mass torts. ${ }^{30}$

Mass tort compensation funds first appeared in China as a result of the 2008 melamine milk scandal. To solve the compensation problem for victims in this incident, 22 wrongdoing milk manufacturers together pooled RMB 200 million to set up a medical compensation fund to cover the medical treatment of victims. This fund was steered by the China Industry Association, which is a quasigovernmental agency. ${ }^{31}$ Likewise, in the 2011 ConocoPhillips oil spill incident, the fisher compensation fund (RMB 1 billion), which was established by ConocoPhillips, was directly managed by the Ministry of Agriculture. ${ }^{32}$ The two recent mass tort incidents cited here show that from its inception, the mass tort compensation fund has been closely linked with the government in China. In other words, the government or its affiliated agencies replace independent professionals as active caretakers for these funds. The main reason for the government's involvement in mass tort compensation funds is to implement the national policy for stability. It is fair to say that political and social stability has been tremendously emphasized by the supreme power since China started its transformation process in the late 1970s. ${ }^{33}$ Because mass tort incidents are always considered by China's top leaders to have the potential to cause instability in society, the government at all levels should engage in the entire process of addressing such events as establishing and running mass tort compensation funds. ${ }^{34}$

The government's engagement, however, also brings bureaucratic practices into the operation of this type of fund, which makes it inefficient, non-transparent and uncertain. ${ }^{35}$ This situation has worsened in the absence of a special law or regulation to govern the life cycle of mass tort compensation funds in China. As such bureaucratic practices become rampant and unbridled in Chinese mass tort compensation funds, the remedial function for mass torts victims regarding the right

30 Id.

31 Xinbo Zhang, Institutional Design of Establishing Mass Tort Compensation Funds 设立大规模侵权损害救济 (赔偿) 基金的制度构想, 6 STUD. IN L. \& Bus. 法商研究 23 (2010).

32 ConocoPhillips China, MOA/SOA Settlements, available at http://www.conocophillips.com.cn/EN/who-we-are/about/ Pages/company-background.aspx (last visited on Oct. 4, 2016).

33 Zhi Rong \& Qixing Chen, Politics of Stability: Revisiting the Dilemma of the Chinese Stability Policy through the Perspective of Political Science“稳定政治”：中国维稳困境的政治学思考, 5 J. PoL. SCI. 政治学研究 87 (2011).

34 Id.

35 Sang Chai, Compensation Dilemma of ConocoPhillips and Flaws of Chinese Institutional Settings 康菲赔偿困局折射 现行体制之歾, available at http://www.time-weekly.com/story/2012-04-12/123488.html (last visited on Oct. 4, 2016). 
to safe food is severely undermined.

\section{B. Government Bailout}

The government bailout represents another remedial measure for victims of mass torts caused by unsafe food in China. To put it simply, the governments administrating the region of the unsafe food producing enterprises would utilize their fiscal revenues to satisfy the compensation claims of victims who have born physical or pecuniary sufferings due to the unsafe food. ${ }^{36}$ The government bailout can be traced back to the "soft budget constraint" practice during the centrallyplanned era of China. ${ }^{37}$ At that time, because Chinese enterprises at all levels were state owned, the governments used to play the role of patron for these enterprises, helping out these affiliated enterprises in case of hardship. ${ }^{38}$ Even though China has nearly given up on its centrally-planned economy, this paternalism by the government has persisted. Especially under the overarching national policy of stability, financial bailout for enterprises that cause mass torts by producing unsafe food has been viewed as the fast track for the governments to ease the fury of masses of victims whose right to safe food has been infringed on by unsafe food. After the breakout of the melamine milk scandal in 2008, e.g., some Chinese local governments even sold parts of their office buildings to raise funds to compensate victims on behalf of milk producers who were the real tortfeasors. ${ }^{39}$

It is evident that government bailout for food safety violations would deviate from the legitimate objectives of public finance. Article 6 of the PRC Budget Law expressly provides that the objectives of public finance are to improve the welfare of citizens, propel economic and social developments, maintain national security, and guarantee the operation of governments. ${ }^{40}$ Even if governments spend their budgets for compensating victims on behalf of wrongdoers in food safety in the name of consolidating social order, it would harm the sustainable social stability in the end. While the governments are concerned about social stability, victims would repeatedly hold up governments to satisfy their compensation claims, which might

36 Qiang Gong, Liheng Lei \& Yan Yuan, Policy Burden, Regulation Capture and Food Safety 政策性负担、规制俘获与 食品安全, 8 ECON. REs. J. 经济研究 5 (2015).

37 Yifu Lin \& Zhiyun Li, Policy Burden, Moral Hazard and Soft Budget Constraint 政策性负担、道德风险与预算软 约束, 2 ECON. RES. J. 经济研究 17 (2004).

38 Id.

39 Tianxiao Bi, Is It Worth Mortgaging Government's Building for the Bankrupt Sanlu? 破产 “三鹿” 值得抵押政府大 院吗?, available at http://opinion.people.com.cn/GB/8582862.html (last visited on Oct. 4, 2016).

40 See the full text of the Budget Law of the PRC, available at http://www.lwrd.gov.cn/art/2015/3/27/art_2560_166740. html (last visited on Oct. 4, 2016). 
even go beyond the reasonable level, thereby threatening to disturb social order. Actually, the government bailout incubates the increasing social instability.

The current Chinese administration and President Xi Jinping have already recognized the malfunctions of the government bailout. They are trying to legalize governmental activities and assess the governments' activities under the rule of law and sustainable development rather than just 'social stability. ${ }^{41}$ Therefore, the traditional government bailout is expected to be gradually replaced by the rule of law principle. Today, it cannot be considered a regular remedial measure for victims whose right to safe food is violated.

\section{Litigation}

For massive victims in food safety incidents, litigation ought to be the last resort to acquire remedies. The PRC Civil Procedural Law provides that mass tort victims are eligible to file lawsuits against wrongdoer enterprises in courts. ${ }^{42}$ Due to the unique political and judicial system, however, Chinese courts are inclined to reject legal proceedings initiated by mass tort victims in practice. ${ }^{43}$

Unlike in the judicial independence model in major western countries, Chinese courts are firmly controlled by the ruling Communist Party of China ("CPC") and tightly constrained by the governments. In particular, Chinese courts on each level are politically subordinated to each Committee of Political Science and Law of the CPC ("CPSL"). The CPSLs are directly monitoring the judicial activities of courts and, inter alia, guaranteeing the implementation of the national policy of stability by the courts. ${ }^{44}$ In addition, the expenditures of Chinese courts on each level mainly come from fiscal revenues of the governments. The governments are thus apt to give priority to fulfilling their own duties when allocating their fiscal revenues. This financial dependence of Chinese courts means that even employing new judges is tightly controlled by the governments. In this context, the governments are usually reluctant to employ sufficient new judges for courts. ${ }^{45}$

41 The Central Committee of the CPC, Decisions of the Central Committee of the CPC on Several Important Issues concerning Full and Further Reform 中共中央关于全面深化改革若干重大问题的决定, available at http://cpc. people.com.cn/n/2013/1115/c64094-23559163.html (last visited on Oct. 4, 2016).

42 The PRC Civil Procedural Law art. 3, available at http://www.gov.cn/flfg/2012-09/01/content_2214662.htm (last visited on Oct. 4, 2016).

43 Wusheng Zhang \& Yanyan Yang, Legislative and Judicial Practice of Mass Litigations in China 我国群体诉讼的立 法与司法实践, 2 CHINESE J. L. 法学研究 112 (2007).

44 Weiguo Wang, Reform of the CPSL 政法委要转变职能, 2 GLoBaL L. REV. 环球法律评论 20 (2013).

45 Weidong Chen, Research on Judicial Independence in China 司法机关依法独立行使职权研究, 2 CHINA L. SCI. 中国 法学 20 (2014). 
The aforementioned system would lead Chinese courts to not adjudicate mass tort cases easily. Due to a great number of victims, particularly, this type of case is fairly complicated. To handle these cases, Chinese courts have to spend more substantial financial and human resources on in-depth investigations. ${ }^{46} \mathrm{~A}$ more important consideration is the legal reasoning of judges that differs widely from that of lay victims. When the verdicts made by judges under the laws are not consistent with the initial expectations of plaintiffs (victims), these numerous victims may engage in radical behaviors, such as violent protests outside the courts, to express their frustrations. If this occurs, CPSL will blame the courts for failing in implementing the national policy of stability. ${ }^{47}$ Because of these dilemmas, Chinese courts are prone to rejecting mass tort cases. The fundamental solution to this problem is thus to continuously push forward Chinese political reform. Because it cannot be achieved overnight, litigation would not be instituted by victims as an efficient remedial measure to restore their right to safe food in China within the foreseeable future.

The above analysis has clearly shown that the Chinese remedial regime for the right to safe food is flawed. To perform the international obligation to protect the right to safe food and to improve its remedial regime, China should adopt the following two approaches. First, China should improve the existing remedial measures for the right to safe food, such as mass tort compensation funds and litigations. Second, China should introduce new measures to enrich the remedial regime in a timely manner. ${ }^{48}$ As far as the second approach is concerned, 'liability insurance' is undoubtedly one of the optimal choices because it can provide efficient and adequate compensation for massive victims whose right to safe food is violated. In accordance with the experiments of voluntary food safety liability insurance in several Chinese regions, moreover, enterprises lack incentives to subscribe to this type of insurance scheme when it is voluntary. ${ }^{49}$ Hence, only CFSLI, rather than a voluntary system, can work for victims in food safety scandals as a new and effective remedial measure. Moral hazards and adverse selection are byproducts of such insurance scheme. They are not, however, unique features of CFSLI. It is therefore unfair to deny the legitimacy and urgency of launching CFSLI in China as 
granted by international human rights law on the basis of these common byproducts of all insurance.

\section{The WTO Legal Regime of Consumer Protection}

As an intergovernmental organization, the World Trade Organization ("WTO") is working for free trade among member States rather than for human rights. However, along with the ever increasing emphasis on protecting human rights on a global scale, the principles of international human rights law have already dominated the law and institution of the WTO. In this vein, leading international economic lawyers have been carrying out academic endeavors to promote humanizing WTO rules to reduce poverty and safeguard consumers' safety and health worldwide. ${ }^{51}$ In response to this type of academic appeal, the WTO itself has taken efficient actions to supply a legal regime to balance free trade and consumer protection for the implicit purpose of fulfilling the human right to adequate food and health, both of which embrace the subordinated right to safe food in the field of international trade.

The WTO legal regime for consumer protection principally consists of two important agreements: Agreement on the Application of Sanitary and Phytosanitary Measures (hereinafter SPS Agreement) and the Agreement on Technical Barriers to Trade (hereinafter TBT Agreement). ${ }^{52}$ The common objective of these agreements is to harmonize free market access of food producers with domestic health regulations of food imports and exports. ${ }^{53}$ They recognize that universally agreed food standards for the protection of consumers bring benefits to both food producers and consumers. ${ }^{54}$ In particular, the SPS Agreement offers a multilateral framework of rules governing the legitimacy of all domestic measures which aim to protect

50 W. Noordhoek, Human Rights in the Law of the World Trade Organization: The Case of the European Generalized System of Preferences, Maastricht Faculty of Law Working Paper 2010/2, available at http://papers.ssrn.com/sol3/ papers.cfm?abstract_id=1537028 (last visited on Oct. 9, 2016).

51 E. Petersmann, Human Rights, International Economic Law and Constitutional Justice: A Rejoinder, 19 Eur. J. InT'L L. 955 (2008), available at http://www.ejil.org/article.php?article=1706\&issue=87\#download_acrobat_reader (last visited on Nov. 5, 2016).

52 See the full text of the SPS Agreement, available at $\mathrm{https} / /$ www.wto.org/english/tratop_e/sps_e/spsagr_e.htm; the full text of the TBT Agreement, available at https://www.wto.org/english/docs_e/legal_e/17-tbt_e.htm (all last visited on Oct. 4, 2016).

53 Id.

54 S. Negri, Food Safety and Global Health: An International Law Perspective, 3 Global Health Gov. 1 (2009). 
consumers' life or health from the risks arising from additives, contaminants, toxins, veterinary drug and pesticide residues, and other disease-causing organisms in foods and beverages. ${ }^{55}$ It may, however, negatively influence the freedom of international trade as advocated by the WTO.

To fulfill the above mission, the SPS Agreement encompasses the elements of precaution and grants to sovereign States the right of imposing restrictions on their food imports and exports for the sake of consumers' health and safety. ${ }^{56}$ Especially in regard to food imports, these domestic restrictive measures should be backed up by sufficient scientific evidence based on an appropriate risk assessment and the principles of non-discrimination and proportionality. ${ }^{57}$ The SPS expressly provides: "There is a right, albeit a conditional right, to take provisional measures subject to the requirements for risk assessment laid out in Article 5.1, 5.5 and 5.6." ${ }^{\text {"58 }}$ Therefore, it is evident that the SPS Agreement attempts to balance the right of sovereign States to determine measures for consumer protection and the freedom of international trade that cannot be hampered by unnecessary, arbitrary, discriminatory, scientifically unjustifiable, or disguised restrictions.

The right of States to adopt restrictive measures for pursuing consumer protection is granted by WTO law. Although it points to both food imports and exports, the existing case law of the WTO primarily focuses on the dimension of food imports. In this type of case adjudicated by the WTO Appellate Body, the Codex Alimentarius has been recognized as the benchmark to assess the legitimacy, appropriateness, and proportionality of restrictions on food imports imposed by sovereign States for the sake of protecting their own domestic consumers. ${ }^{59}$ In EC-Sardines and EC-Hormones, the WTO Appellate Body confirmed its recognition of the standards of the Codex Alimentarius as "relevant international standards" to be relied on by States as a basis for their food import restrictions, implying that such standards might be adopted without consensus. ${ }^{60}$ It is thus fair to say that, through adjudicating these foodimport-related cases, the Appellate Body has clearly shown its stance that "the WTO cannot and does not stand for free trade at any cost" and that remarkable emphasis should be put on the importance of internationally accepted food standards for "upholding a rules-based multilateral trading system that ensures secure and

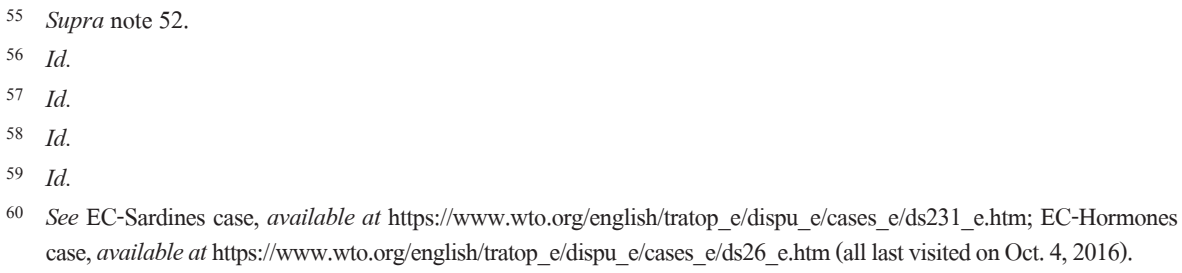
case, available at https:/www.wto.org/english/tratop_e/dispu_e/cases_e/ds26_e.htm (all last visited on Oct. 4, 2016). 
predictable market access, while respecting health and [safety] concerns.,"

Apart from the food import restrictions, the right of States to adopt restrictive measures to enhance consumer protection under the WTO legal regime refers to the field of food exports, as well. Even though food export restrictions attract less attentions by the WTO Appellate Body than the aforementioned food import restrictions featured with multilateral influences, at the sole discretion of States, they exhibit commitment to safeguard foreign consumers' health and safety which are fundamental human rights in trade. A number of sovereign States including China have voluntarily decided to exercise the right of food export restrictions that is granted by the WTO law against domestic food producers in the interests of foreign consumers. ${ }^{62}$ Unfortunately, few academic discussions have been contributed to this area thus far.

To summarize, the core values of international human rights law have also been recognized by the WTO law. The legal regime of the WTO concerning consumer protection represents the endeavors made by this intergovernmental organization, other than maintaining free trade among member States, to protect and enhance two fundamental human rights, i.e., the right to adequate food and the right to health both of which are affiliated to the right to safe food. Under this legal regime, sovereign States have been granted the right to impose restrictions on food imports or exports in the interest of consumers' health and safety. It is argued that both dimensions of food import restrictions and food export restrictions should be equally emphasized by academia.

\section{The Commodity Export Inspection System in China: Flaws and CFSLI}

As discussed above, under the WTO legal regime, sovereign States are committed to guarantee and reinforce food safety in the domain of trade. This is largely displayed by their voluntary exercise of the right to take restrictive measures, primarily granted by and pursuant to the SPS Agreement and the TBT Agreement, against food imports and exports for the sake of consumer protection. As a member State

61 S. Shaw \& R. Schwartz, Trading Precaution: The Precautionary Principle and the WTO, available at http://collections. unu.edu/eserv/UNU:3103/Precautionary_Principle and_WTO.pdf (last visited on Oct. 4, 2016).

62 Apart from the Chinese Commodity Import and Export Inspection System, the US also maintains the Federal Grain Inspection Service System. 
of the WTO since 2001, China has followed the instruction of the WTO legal regime concerning consumer protection to voluntarily maintain the commodity import and export inspection system which is domestically governed by the Law of the PRC on Commodity Import and Export Inspection (hereinafter CIEI Law). ${ }^{63}$

Article 1 of the CIEI Law provides that the objectives of this Law are to strengthen and regulate commodity import and export inspection, protect public interests and legitimate interests of trade parties of imports and exports, and facilitate the development of international trade. ${ }^{64}$ In addition, Article 4 of the CIEI Law provides that commodity import and export inspection ought to be based on the principles of safeguarding human beings' health and safety, protecting the life and health of animals and plants, protecting environments, preventing deceptive behaviors and maintaining the security of sovereignty. ${ }^{65}$ It is evident that the CIEI Law has absorbed the basic principles of the WTO legal regime concerning consumer protection that free trade and consumer protection should and could be harmonized via implementing the commodity import and export inspection system.

However, because the 2008 Chinese melamine milk scandal also seriously harmed the safety and health of foreign consumers through toxic milk exports, it has revealed that commodity export inspection in China is not a seamless web, but is fraught with flaws. In turn, the flawed commodity export inspection system has undermined China's commitment to protect consumers under WTO law. Moreover, it has tainted the image of Chinese domestic producers and reduced the competitiveness of their commodities in the global market. ${ }^{66}$ It is thus necessary for China to renovate the dysfunctional commodity export inspection system as a fundamental stepping stone.

Given the constraints of the Chinese institutional settings, however, the mending process in this regard will take quite a long time. To supplement the porous commodity export inspection system which acts as an ex ante mechanism for consumer protection, CFSLI should be urgently launched as an ex post measure by the Chinese authorities. It may further improve China's voluntary exercise of the right of trade restrictions in the interests of consumers under the WTO law.

The following two factors would increase the daily workload of the commodity export inspection bureaus and their daily sample experiment frequency.

\footnotetext{
63 See the full text of the CIEI Law, available at $\mathrm{http} / /$ www.cnca.gov.cn/mra/NewZealand/flfg/fl/46210.shtml (last visited on Oct. 4, 2016).

64 Id.

65 Id.

66 Supra note 1.
} 


\section{A. Personnel Quota and Limited Human Resources}

China has been operating a rigid personnel quota system for governments since the central-planned economic era. ${ }^{67}$ Due to this inflexible and outdated system, the headcount of each governmental agency is fixed and cannot be easily changed. ${ }^{68}$ The rigid personnel quota has often placed increasing workloads on commodity export inspection bureaus with the limited human resources.

Since the late 1970s when the reform and opening-up policy was launched, China's commodity exports have been rapidly increasing on a yearly basis to become the largest export country in the world. ${ }^{69}$ Pursuant to the CIEI Law, the commodity export inspection bureaus are required to test a sample of each batch of exported commodity before it is freighted out of the country's borders. ${ }^{70}$ Because of the headcount of the commodity export inspection bureaus, which has been firmly controlled and rigidly fixed by the personnel quota system, however, the bureaus cannot recruit a sufficient number of full-time professional inspectors to perform their duties. ${ }^{71}$ To partially relieve themselves of this dilemma, China commodity export inspection bureaus have started to employ a number of part-time inspectors. As these part-time inspectors receive only very basic inspection training and work on the front line, ${ }^{72}$ however, they have often been negligent in the process of inspection. Pursuing this approach would further jeopardize the interests of foreign consumers. $^{73}$

\section{B. Assorted Standards and Local Interests}

The second factor in the dereliction of duty in the process of commodity export inspection in China is the interests of local governments. At the end of 1993, the CPC and Chinese central government launched a tax-revenue-division reform. ${ }^{74}$ Pursuant to the reform, China's annual tax revenues have been split between the central and

67 Xiaoyi Zhai, Examining Part-time Employment under the Personnel Quota System of Chinese Governments 地方政府 编外用人现象探析, 3 EXPANDING HoRIZONS 新视野 49 (2010).

68 Id.

69 Yi Zhang, Some Suggestions on Improving the Commodity Import and Export Inspection System in China 关于我国进 出口商品检验制度改革的思考, available at http://wZzx.71.cn/2011/0302/601774.shtml (last visited on Oct. 4, 2016).

70 Id. See also CIEI Law art. 5.

71 Supra note 69.

72 Id.

73 Id.

74 The PRC State Council, Decision on the Implementation of the Tax-Revenue-Division Reform, available at http:// govinfo.nlc.gov.cn/lssj/xxgb/ahszfgb/199402/201104/t20110414_705268.html?classid=363 (last visited on Oct. 4, 2016). 
local government with a new set of criteria. The implementation of this new tax allocation formula has fundamentally changed the fiscal abilities of the central and local government of China, respectively. As statistics show, the ratio of fiscal income of the Chinese central government to that of local governments was 22/78 and the ratio of fiscal expense was $28 / 72$ in 1993 . In 2008, the two ratios changed to $53 / 47$ and $21 / 79 .^{75}$

Table 1: Ratio of Fiscal Incomes and Expenses between the Chinese Central Government and Local Governments in 1993 and 2008 ${ }^{76}$

\begin{tabular}{|c|c|c|c|}
\hline \multirow{2}{*}{ Year } & \multicolumn{2}{|c|}{ Fiscal Income Ratio (\%) } & Fiscal Expense Ratio (\%) \\
\hline \multirow{2}{*}{1993} & Central & 22 & 28 \\
\cline { 2 - 4 } & Local & 78 & 72 \\
\hline \multirow{2}{*}{2008} & Central & 53 & 21 \\
\cline { 2 - 4 } & Local & 47 & 79 \\
\hline
\end{tabular}

Source: Compiled by the author

The two sets of data clearly indicate that since the tax-revenue-division reform, Chinese local governments have been given a smaller piece of the tax-revenue pie contributing more financial strength to make the pie bigger. Also, the "one-veto-all criterion” (一票否决制度) of China's official promotion system should be considered. This means that a government leader can never get promoted if $\mathrm{s} /$ he fails to fulfill one crucial task assigned by the superior government. It puts huge pressure on the local government.

Consequently, these sub-factors have provided senior local officials with strong incentives to explore ways to substantially increase local fiscal incomes to successfully complete heavy tasks saddled by superior governments. In this vein, commodity exports represent a lucrative approach for local governments to enlarge their fiscal revenues. ${ }^{77}$ Therefore, they hold a very positive attitude toward pushing commodity exports and try their best lobbying commodity export inspection bureaus to apply inspection standards in a loose manner.

75 Yaobin Yan, Land Financing Constrains the Enactment of the New House Relocation Regulation 受制土地财政《新 拆迁条例》难产, ChINA Bus. J.中国经营报, July 26, 2010, at B7.

76 Id.

77 Rongjun Zhou, Hui Wang \& Cinan Ye, Factors Influencing the Fiscal Revenues of Shanghai 浅析影响上海市财政收 入的因素, 5 Northern ECON. Trade 北方经贸 31 (2004). 
Today, the commodity export inspection bureaus in China rely on the rules and standards of destination countries to inspect exported commodities. ${ }^{78}$ Because each jurisdiction maintains its own distinctive inspection standards for any given commodity, it is very difficult for Chinese inspectors to be acquainted with all of these standards. ${ }^{79}$ In particular, a large portion of Chinese inspectors are lesstrained, part-time employees, most of whom lack the capability to accurately handle these assorted standards. ${ }^{80}$ It is thus inevitable that sloppy and rough inspections frequently occur in practice.

\section{Conclusion}

The above description has sketched out the current Chinese commodity export inspection system, which is riddled with flaws. It is clear that some of the flaws are fundamentally ascribed to the institutional settings of China, such as the governmental personnel quota system and the fiscal allocation system. Thus, improving the Chinese commodity export inspection system must be accomplished in collaboration with the political reform of Chinese governments. Otherwise, it is destined to fail. However, China's political reform is a long-term project. Consequently, the improvement of the Chinese commodity export inspection system will also take a long time.

Under such circumstances, to reinforce China's exercise of the right to take trade-related restrictive measures for consumer protection as granted by the WTO law, post ante measures should be introduced by the Chinese authorities. It is an alternative to continuously and incrementally improving the commodity export inspection system, which represents an ex ante mechanism. In this regard, CFSLI is undoubtedly an optimal option considering its outstanding remedial function for consumers. Therefore, apart from international human rights law, it is also supported by the WTO law that China ought to launch CFSLI in a timely manner.

Globalization brings us an interconnected forum that can be also applied to legal research. To mitigate the serious food safety problem in China, there is an urgent need for CFSLI to be launched by the Chinese authorities. As verified by this research, the legitimacy of CFSLI in China is not only rooted in domestic laws, 
but also embedded in public and private international law in its broad sense. In particular, governed by the human right perspective, public international law and broadly-interpreted private international law have already twisted their arms to collectively support the Chinese CFSLI attempt. On the one hand, this attempt helps China to better perform its international obligation to protect the subordinated human right to safe food. On the other hand, it also facilitates and reinforces China's exercise of the right of taking trade-related restrictive measures for consumer protection.

Examining CFSLI from a viewpoint of international law, it further provides two valuable points for legal research in the future. First, the holistic approach covering domestic and international law must be noted when scrutinizing a legal phenomenon. Second, the ideology and principles of public international law must be emphasized when analyzing private international law broadly, and vice versa. It is fair to say that, in terms of core values and methodologies, public international law and broadly-interpreted private international law are increasingly converging with each other rather than diverging. 